\title{
Ludność polska Wołynia i Galicji Wschodniej wobec mordów ukraińskich w latach 1943-1944. Antropologia strachu
}

Zarys treści: Głównym celem niniejszego artykułu jest analiza jednego z podstawowych determinantów działań obronnych Polaków na Wołyniu i w Galicji Wschodniej wobec polityki eksterminacyjnej nacjonalistów ukraińskich w latach 1943-1944. Tym determinantem był strach, który w różnych formach i rozmaitym natężeniu dotknął całą zagrożoną eksterminacją ludność polską w obu regionach. Analiza jego przejawów pozwala wysnuć wniosek, że strach stał się głównym imperatywem pierwszych, jeszcze niezinstytucjonalizowanych działań obronnych Polaków.

Slowa kluczowe: Wołyń, Galicja Wschodnia, II wojna światowa, eksterminacja, Polacy, ukraińscy nacjonaliści, strach

Key words: Volhynia, Eastern Galicia, World War II, extermination, Poles, Ukrainian nationalists, fear

Eksterminacja Polaków na Wołyniu i w Galicji Wschodniej dokonywana przez nacjonalistów ukraińskich od 1943 r. była zjawiskiem polityczno-społecznym, w którym można wyodrębnić różne czynniki. Te główne, dotyczące jej przyczyn, przebiegu i konsekwencji (zwłaszcza w makroskali) są przedmiotem analiz historyków, jednak ich wyniki są wielokrotnie rozbieżne. W badaniach nad sekwencjami mordów ważne wydaje się wskazanie zarówno punktów zwrotnych, nadających działaniom ludzkim określoną dynamikę, jak i przesłanek, które doprowadziły do przełomu. Wiąże się to $\mathrm{z}$ analizą indywidualnych zachowań człowieka. Trudność w tych badaniach polega głównie na dotykaniu emocjonalnej sfery osobistej, skonfrontowanej z ekstremalnymi warunkami zewnętrznymi. Ten wycinek historii społecznej Kresów Wschodnich II RP w latach 1939-1945 wciąż nie doczekał się odrębnej analizy naukowej.Eksterminację ludności polskiej Wołynia i Galicji Wschodniej można badać m.in. jako proces społeczny. W tej perspektywie punktem wyjściowym 
eksploracji powinno być ustalenie, które zjawiska, kiedy i w jaki sposób wpłynęły na reakcję Polaków wobec niej. Przekaz z materiałów źródłowych nie pozostawia wątpliwości, że głównym bodźcem decydującym o pierwszych indywidualnych postawach wobec zabijania był strach.

Zjawisko strachu jest trudną kategorią badawczą, wymykającą się wszelkim statystykom w historiografii. Trudność wynika z faktu, że jest to intymna sfera każdego człowieka, który może reagować na niego w różny, często nieprzewidywalny sposób. Warto podkreślić, że strach (rozumiany również jako lęk, terror lub niepokój) człowieka jako istoty społecznej żyjącej wśród ludzi będzie zawsze najsilniejszy właśnie w relacjach międzyludzkich ${ }^{1}$.Polacy na Wołyniu i w Galicji Wschodniej od października 1939 r. żyli pod władzą dwóch totalitaryzmów - radzieckiego i niemieckiego. W okresie rządów sowieckich wiele ich rodzin doświadczyło deportacji, aresztowań, skazywania, różnorodnych form szykanowania i dyskryminacji przez władze państwowe. Spotkało się to z aprobatą części ukraińskich i żydowskich sąsiadów Polaków. W subiektywnym odczuciu ludności polskiej były to działania niesprawiedliwe. Można sądzić, że duży wpływ na obecność strachu w jej życiu codziennym miały właśnie postawy ich niepolskich sąsiadów. Oni, przynajmniej częściowo wspierani przez władzę radziecką, mogli dawać w różnych formach upust niechęci wobec niedawnych włodarzy tych ziem. Jednak dopiero okres rządów niemieckich - totalitaryzmu w warunkach wojennych - wprowadził do życia codziennego Wołynia i Galicji Wschodniej powszechny widok śmierci i zastraszania całych społeczności. Holocaust ludności żydowskiej był procesem, w który Niemcy wprzęgli pozostałych mieszkańców tych ziem. Np. w powiecie Skałat w Galicji Wschodniej hitlerowcy zmuszali Polaków do zakopywania ciał zamordowanych Żydów. Ta czynność powodowała u niektórych występowanie szoku nerwowego, który w skrajnych wypadkach kończył się śmiercią przymusowych grabarzy². Traumatycznymi przeżyciami były pacyfikacje wsi polskich i ukraińskich przez brunatnych okupantów (podpalali całe osady), wywózki na roboty przymusowe do Niemiec, pokazowe egzekucje oraz szykany policji ukraińskiej na służbie nazistów. W rezultacie zapanowała anarchia i terror. Jego zawsze najgroźniejszą konsekwencją jest stworzenie z przemocy centralnej zasady regulującej życie społeczne ${ }^{3}$. Na Wołyniu i w Galicji Wschodniej w 1943 r. ta zasada stawała się coraz powszechniejsza.

Nieprzypadkowo wspomniałem o Holocauście. Eksterminacja miejscowych Żydów była widoczna i większość ich sąsiadów o niej wiedziała. Niektórzy autochtoni czynnie lub biernie ją wspomagali. Inną, nie zawsze dostrzeganą przez historyków konsekwencją tego ludobójstwa był bardzo groźny proces oswajania się mieszkańców Wołynia i Galicji Wschodniej z obrazem zbrodni, nierzadkim widokiem śmierci. To powodowało, że obecność strachu wśród Polaków w życiu codziennym w porówna-

\footnotetext{
1 J. Pieter, Strach i odwaga, Warszawa 1971, s. 87.

2 Sz. Siekierka, H. Komański, Ludobójstwo dokonane przez nacjonalistów ukraińskich na Polakach w województwie tarnopolskim 1939-1946, Wrocław 2006, s. 816.

3 A. Appadurai, Strach przed mniejszościami. Esej o geografii gniewu, Warszawa 2009, s. 38.
} 
niu z czasami sowieckimi wzrosła. Można zaryzykować tezę, iż na trwałe zagościł on w ich umysłach i w jakiś sposób spowszedniał. Również do pewnego stopnia przekonstruował ludzką psychikę, obliczoną już tylko na strategię przetrwania. Nie należy zapominać, że poczucie strachu musiało być inne w warunkach, kiedy człowiek był obserwatorem eksterminacji, a ten proces nie dotyczył bezpośrednio jego oraz społeczności do której należał. W tym okresie Ukraińcy dopuszczali się wobec Polaków aktów pobicia, rabunków ${ }^{4}$, grożenia, poniżania, podpaleń, ograniczenia swobody poruszania się, nieudanych zabójstw i wymuszania kontyngentów na rzecz UPA $^{5}$. Były to jednak najczęściej działania pojedyncze, nietworzące wśród ludności wrażenia o ich odgórnym zorganizowaniu. To powodowało m.in., że informacje o zagrożeniu ukraińskim przyjmowano z niedowierzaniem. Dotyczyło to zwłaszcza przedstawicieli starszego pokolenia, którzy dość uparcie twierdzili, że niemożliwe jest mordowanie niewinnych ${ }^{6}$.

Fala strachu w obu regionach wyraźnie wzrosła wczesną wiosną 1943 roku. Po zabójstwie przez Polaków ukraińskiego nacjonalisty Onyszkiewicza z Uhnowa (powiat Rawa Ruska), Ukraińcy obwieźli jego ciało trzykrotnie wokół rynku w tej miejscowości i trzykrotnie publicznie przysięgali, że „noga polska nigdy nie stanie na ziemi uhnowskiej"7 . Coraz częstsze stawało się malowanie w nocy na domach Polaków krzyży, ilościowo równych liczbie członków rodziny. Natomiast domy ukraińskie znaczono niezrozumiałą dla nas liczbą „102”. Pesymizm, o ile nie fatalizm Polaków przejawiał się w tym, że interpretowano ją jako liczbę dni pozostałych do ostatecznego rozprawienia się z nimi. Podobne sposoby myślenia występowały dość powszechnie ${ }^{8}$.

Informacje o pierwszych mordach całych skupisk ludzkich na Wołyniu w lutym 1943 r. bardzo szybko rozprzestrzeniły się wśród ludności polskiej. Osobami powiadamiającymi byli uczestnicy wydarzeń, którym udało się uciec. Trudno rozstrzygnąć, czy wszyscy uwierzyli „mrożącym krew w żyłach” relacjom, które mogły wydawać się nieprawdopodobne ${ }^{9}$. Wydaje się, że większość Polaków jednak dała im wiarę.

${ }^{4}$ AW, II/1145, k. 1, H. Kulczycka, Moje przeżycia na Wołyniu po wybuchu II wojny światowej.

${ }^{5}$ W. E. Siemaszko, Ludobójstwo dokonane przez nacjonalistów ukraińskich na ludności polskiej Wołynia 1939-1945, t. 1, Warszawa 2000, s. 34. Działania Ukraińców, które zastraszały Polaków, polskie podziemie nazwało dobitnie „propagandą grozy”. Zob. BUW, mikrofilm 14381, k. 28, Raport „Janki” [W. Filipkowskiego] z 6 III 1944 roku.

${ }^{6}$ Por. IPN Ki., GKBZPNP OK/Koszalin, 53/1257, k. 4, Protokół przesłuchania świadka J. Gryciuka; Władysław Żarczyński, Byłem świadkiem, „Na rubieży”, nr 33-34/1999, s. 56.

7 IPN Ki., 53/1046, k. 115, Akta b. OKBZH Kielce „Wieś polska na Kresach Wschodnich 1939-1945”. Sesja w Ameliówce 22-24 V 1999 roku.

${ }^{8}$ W. E. Siemaszko, op. cit., s. 139. Także w innych miejscowościach Polacy doszukiwali się w zachowaniach Ukraińców ukrytych intencji. Te postawy nasiliły się wraz z kolejnymi doniesieniami o mordach. We wsi Głęboczyca (powiat Włodzimierz Wołyński) wśród ludności polskiej panowało przekonanie, że Ukraińcy w swoich bryczkach po to wożą łopaty, aby po zabiciu Polaka natychmiast go zakopać, a tym samym ukryć ślady zbrodni. Zob. więcej: IPN Ki., GKBZPNP OK/Koszalin, 53/1274, k. 6, Protokół przesłuchania świadka K. Sobieraja.

9 Por. IPN Ki., GKBZPNP OK/Koszalin, 53/1244, k. 2-3, Protokół przesłuchania świadka B. Parchoć; E. Zawada, Akcja SS „Galizien” w Siemianówce dnia 26 VII 1944 roku, „Na rubieży”, nr 66/2003, s. 39; Tadeusz Maławski, Byłem świadkiem, „Na rubieży”, nr 73/2004, s. 33. 
Przemawiał za tym m.in. powszechniejszy od pewnego czasu widok trupów płynących rzekami wołyńskimi ${ }^{10}$. W zasięgu wzroku znajdowały się okoliczne, coraz częściej płonące wsie. Łuny ognia od podpaleń były widoczne w promieniu wielu kilometrów, a zdarzało się również, że krzyki i płacz palonych ludzi słyszano w okolicznych osadach polskich ${ }^{11}$. Niektórzy z ich mieszkańców już kilka godzin później uczestniczyli w identyfikacji zmasakrowanych najczęściej zwłok ofiar. Trudno obecnie zweryfikować jakość przekazywanych rodzinie i sąsiadom informacji świadków masakr o ich przebiegu. Te wiadomości pochodziły od doznających silnego szoku, ale jak się wydaje, niczego nie ubarwiano ani nie wyolbrzymiano. To pojawiało się dopiero w dalszym obiegu informacji, kiedy kolejne osoby mogły je świadomie lub nieświadomie zniekształcać. Obecność plotek o organizowaniu przez Ukraińców podobnych rzezi w zachodniej, etnicznie niemal zupełnie polskiej Galicji jest tego dobrym przykładem ${ }^{12}$. Można mieć pewność, że treść zarówno prawdziwych informacji, jak i już przetworzonych pogłębiała uczucie strachu.Okrutny sposób przeprowadzania masakry przez cały okres jej trwania był znany Niemcom, którzy raportowali, że w rejonach „,czysto polskich” powstało duże zamieszanie i panika ${ }^{13}$. Również podziemie akowskie oraz działające legalnie agendy Rady Głównej Opiekuńczej alarmowały, że zorganizowana akcja mordowania Polaków „powoduje ogólną psychozę strachu i paniki”. Według nich upowcy wybrali dobry moment ataku, gdyż ludność polska „żyje jak na wulkanie”, w napięciu nerwowym, zupełnie nie panuje nad sobą, a dominuje wśród niej depresja, pesymizm i fatalizm ${ }^{14}$. MSW polskiego rządu emigracyjnego informowało, że wśród ludności polskiej rozrzuconej wśród większych skupisk ukraińskich panuje stan silnego zdenerwowania i rosnącego niepokoju, a wieści paniczne przyjmują się bardzo łatwo i budzą myśli o ucieczce ${ }^{15}$.

Wydaje się, że to właśnie panika stała się podstawowym przejawem strachu Polaków. Wynikała $\mathrm{z}$ faktu, że cała ludność polska w obu regionach, a nie tylko jej warstwa kierownicza została skazana przez Ukraińców na zagładę, którą planowo realizowali. Wobec wieści o charakterze masakr wydaje się, że była zjawiskiem nieuniknionym. Powstaje pytanie, czy banderowcy liczyli na wybuch paniki wśród Polaków, która zmusi ich do opuszczenia tych ziem? Niewykluczone, że początkowo miała być ona narzędziem prowokującym opornych do emigracji. To okazało się mało skuteczne. Z perspektywy nacjonalistów ukraińskich bez wątpienia jednak ułatwiała zabijanie

${ }_{10}$ M. Dębowska, L. Popek, Duchowieństwo diecezji łuckiej. Ofiary wojny i represji okupantów, Lublin 2010, s. 196.

${ }^{11}$ Por. W. E. Siemaszko, op. cit., s. 79; IPN Ki., GKBZPNP OK/Koszalin, 53/1258, k. 3, Protokół przesłuchania świadka T. Strusia.

12 AW, V/1, k. 3, Kolekcja Wojciecha Bukata, Sprawozdanie m.t. 16-k2 z 19 V 1944 roku.

13 Die UPA in Halychyna, UPA w switli nimećkych dokumentiw, Litopys UPA, t. 6, Toronto 1983, s. 139.

14 Por. DATO, f. R-3445, op. 1, spr. 29, k. 6, Fragment raportu „Więcława” z 5 III 1944 r. o powiecie Borszczów; BOss., 16623/II, k. 17, Meldunek tygodniowy WIiP ODR z terenu województwa tarnopolskiego i powiatu Rohatyń za dni 10 X - 18 XII 1944; BOss., 16721/II, k. 8, Papiery RGO dotyczące sytuacji ludności polskiej w Małopolsce Wschodniej w latach 1943-1944.

15 CAW, II/52.85, k. 63, Sprawozdanie sytuacyjne nr 11 emigracyjnego MSW RP za VII-VIII 1943 roku. 
niezorganizowanej ludności. Większość Polaków na Wołyniu i w Galicji Wschodniej zamieszkujących obszary wiejskie była religijna, mocno związana z tradycjami Kościoła rzymskokatolickiego. Banderowcy nieprzypadkowo wybierali szczególne dni jako daty masakr - ich duże nasilenia miały miejsce w latach 1943-1944 w okresie Świąt Wielkanocnych, w noc wigilijną, Święta Bożego Narodzenia oraz w innych dniach okolicznościowych ${ }^{16}$. Zbrodnie odbywały się również $\mathrm{w}$ kościołach, także $\mathrm{w}$ czasie mszy. Te daty i miejsca były dla wiernych święte, a morderstwa w miejscach kultu religijnego uznawali za wielką profanację. Jak się wydaje, większość zagrożonych nie interpretowała wydarzeń jako kary bożej za ich grzechy i nie utraciła wiary. Przeciwnie, wielu traktowało modlitwy jako panaceum na strach. Powszechne stało się czuwanie nocami po domach w kilkuosobowych grupach - wówczas przed obrazami o tematyce sakralnej odmawiano „Pod Twoją obronę"17. Natomiast rankiem składano modlitwę dziękczynną za to, że noc upłynęła spokojnie. Pieśni religijne śpiewały w miejscach kaźni klęczące kobiety i dzieci, przestraszone, że czeka je śmierć ${ }^{18}$. Obecność modlitw ukazywała wolę Polaków oddania swojego losu w ręce Stwórcy oraz ich silnej, jak się wydaje, nieskruszonej wydarzeniami wiary.

Oprócz paniki na rozprzestrzenianie się strachu duży wpływ miało zachowanie Ukraińców w trakcie napadów. Niektórzy z morderców byli dobrze znanymi Polakom sąsiadami, znajomymi, z którymi relacje wcześniej określano jako poprawne, a nawet bardzo dobre ${ }^{19}$. Ten zwrot $\mathrm{w}$ ich postawie stał się nie tylko niezrozumiały, ale także budził grozę. W trakcie napadów zdarzało się, że banderowcy przygrywali na harmonii ${ }^{20}$. Znaleźli się świadkowie żartów napastników na tematu wyglądu zabijanych właśnie kobiet. Inni obserwowali powrót upowców z akcji eksterminacyjnej; każdy z nich miał pobrudzoną twarz i odzież jeszcze niezakrzepłą krwią oraz sadzą. W niektórych wypadkach napadający mieli na twarzach maski ${ }^{21}$. Zdarzało się, że widziano z ukrycia tuż po masakrze libacje rodzin ukraińskich odbywające się przy suto zastawionych stołach, alkoholu i wesołej muzyce ${ }^{22}$. To musiało demonizować obraz Ukraińca w umyśle miejscowego Polaka i zapewne zamazywać świadomość, że wielu $\mathrm{z}$ nich pomagało $\mathrm{w}$ ukrywaniu się i ucieczce zagrożonym osobom.

Wiedza o mordach na ludności polskiej obejmowała również jej najmłodsze pokolenia. Dzieci wielokrotnie były świadkami napadów, a ich pamięć dokładnie rejestrowała wrzaski zabijanych ludzi ${ }^{23}$. Strach przybierał tutaj formę koszmarów sennych, które pozostały niektórym na całe życie. Nieobce również były mocze-

\footnotetext{
16 Ibidem, k. 283.

17 J. Wołczański, Eksterminacja narodu polskiego i Kościoła rzymskokatolickiego przez nacjonalistów ukraińskich w Małopolsce Wschodniej w latach 1939-1945. Materiały źródłowe, cz. I, Kraków 2005, s. 103.

18 Por. Relacja świadka Aleksandra Praduna, „Na rubieży”, nr 2/1993(3), s. 6; BOss., 16726/II, k. 203, Edmund Bosakowski, „Na mojej drodze. Wspomnienia z Wołynia z lat 1939-1945”.

19 Ibidem, k. 200.

20 J. Wołczański, op. cit., cz. I, s. 103.

${ }^{21}$ Sz. Siekierka, H. Komański, op. cit., s. 485.

22 W. E. Siemaszko, op. cit., s. 147, 150, 507.

${ }^{23}$ AW, II/2311, k. 31, Rozwadowski Piotr, 14 lipca 1943 r. dniem zagłady Polaków mieszkańców
} Kołodna. 
nia nocne, płacze, lamenty i krzyki przez sen ${ }^{24}$. Pojawiły się także choroby fizyczne wywołane paraliżem ze strachu i szokiem nerwowym. W pojedynczych przypadkach jego widoczną konsekwencją stało się osiwienie w nastoletnim wieku ${ }^{25}$. Najbardziej skrajnym rezultatem strachu były choroby psychiczne; część ocalałych z pogromu postradała zmysły - takie sytuacje miały miejsce m.in. we wsi Hołosków w powiecie tłumaczowskim oraz wśród uciekinierów obozujących w Równem ${ }^{26}$.

Polskie podziemie oceniało, że tylko przełamanie strachu ludności umożliwi jej obronę przed zagładą. O tym, że jest on powszechny również wśród polskich partyzantów zdawano sobie sprawę. Niektóre wytyczne odnoszące się do walki z Ukraińcami już w pierwszych słowach nawoływały: „W tych ciężkich chwilach nie wolno poddać się rozpaczy (...) W chwili napadu postawa wasza ma być męska, walczyć macie jako żołnierze"27. Te sformułowania były wręcz nakazywaniem odwagi. Jak się wydaje, mało kto w podziemiu zdawał sobie sprawę, że podstawowa trudność polegała na tym, że obiekt budzący bardzo silny strach powodował rodzaj zahipnotyzowania świadomości ${ }^{28}$, a to nie sprzyjało racjonalnemu działaniu. Powstaje pytanie, czy udawało się przełamać strach, a w konsekwencji bezsilność.Dla ludności polskiej podstawowym problemem była bezbronność. Znacząco pogłębiała ona strach oraz powodowała spontaniczne decyzje o ucieczce ${ }^{29}$. W raportach podkreślano, że nastrój przygnębienia Polaków przeplata się z determinacją, chęcią obrony i rewanżu Ukraińcom, jednak braki w uzbrojeniu to uniemożliwiają ${ }^{30}$. Prośby u Niemców o broń przybierały niekiedy formy błagania. Czynili to również miejscowi polscy księża, którzy rozumieli, że tylko pomoc militarna przywróci zagrożonym wiarę w sens samoobrony i zniechęci do ucieczki ${ }^{31}$. W niektórych miejscach, gdzie pojawiały się pierwsze pomysły tworzenia przez młodzież oddziałów partyzanckich (np.

24 Byłem świadkiem - Władysław Biliński, „Na rubieży”, nr 65/2003, s. 45.

${ }^{25}$ L. Kulińska, Dzieci Kresów II, Kraków 2006, s. 144.

${ }^{26}$ Por. Sz. Siekierka, H. Komański, E. Różański, Ludobójstwo dokonane przez nacjonalistów ukraińskich na Polakach w województwie stanisławowskim 1939-1946, Wrocław 2008, s. 693; BOss., $16727 /$ II, k. 93, Regina Janiszewska-Wolska, Na Wołyniu w latach okupacji 1939-1945 (Równe Wołyńskie) we wspomnieniach.

27 DATO, f. R-3445, op. 1, spr. 48, k. 1, Rozkaz do żołnierzy podpisany przez „Cisa” [W. Filipkowskiego] - Komendanta Południowo-Wschodnich Sił Zbrojnych w Kraju z dnia 25 II 1944 roku.

${ }^{28}$ J. Pieter, op. cit., s. 169.

29 BOss., 16605/II, k. 209, Raport o nastrojach ludności polskiej na terenach powiatu lwowskiego w związku ze wzmagającą się akcją terrorystyczną ukraińską, oprac. „Jan”, Lwów 23 IV 1944 roku.

30 BUW, mikrofilm 14381, k. 24, „Meldunek doraźno-informacyjny” „Janki” [W. Filipkowskiego] nr 7 z 1 III 1944 roku.

31 BOss., 16605/II, k. 209, Raport o nastrojach ludności polskiej na terenach powiatu lwowskiego... Także wśród księży rzymskokatolickich dał się zauważyć nastrój silnego strachu i zwątpienia, co musiało osłabiać wagę ich pocieszających kazań i innych form wspierania duchowego Polaków. Ksiądz K. Bartosiewicz z parafii Zawałów napisał 3 II 1944 r. list do Kurii Metropolitalnej obrządku łacińskiego we Lwowie. Zawarł w nim następujące słowa: „Upraszam o łaskawe udzielenie mi urlopu zdrowotnego na 1 miesiąc, ponieważ nerwowo jestem prawie zupełnie wyczerpany z powodu tych rzezi, jakie dokonują się w okolicznych wioskach. Już 2 tygodnie prawie nie śpię zupełnie po nocach i nie nocuję na plebani i ciągle słyszę pogróżki pod moim adresem. Rozumiem dobrze swój kapłań- 
w okolicach Włodzimierza Wołyńskiego), nastroje i morale oceniano jako dobre, nie odnotowywano objawów paniki ${ }^{32}$. Trudno to uznać za regułę. We wsi Sawosze na Wołyniu istniał pluton konspiracyjny AK, tworzący samoobronę. Mimo tego, na wieść o rzeziach w pobliskiej Woli Ostrowieckiej w miejscowości 31 sierpnia $1943 \mathrm{r}$. zapanowała panika i nikt z sawoszan nie wierzył w skuteczność samoobrony ${ }^{33}$.

Opanowanie paniki było zadaniem trudnym. Podziemie wskazywało, że zaradzi jej tylko wprowadzenie reguł surowej dyscypliny wśród mieszkańców danej miejscowości. Nie zawsze przynosiło to oczekiwany skutek. Zdarzało się, że ogarnięci strachem uznawali otrzymane wskazówki za „czysto papierową robotę, nie popartą bronią"34.

Także w punktach samoobron, zwłaszcza tych nietworzących zwartego kompleksu zabudowań, panika występowała dość często. W różnych, także wyszukanych formach ich kierownictwo próbowało jej zaradzićs ${ }^{35}$. Przyczynami upadków ośrodków były nie tylko braki w uzbrojeniu i wyczerpanie fizyczne walką. Bardzo istotne było również wyczerpanie psychiczne ${ }^{36}$, a więc rodzaj napięcia, które strach determinował.

To zjawisko w najskrajniejszych formach dotknęło ludność polską na Wołyniu i w Galicji Wschodniej w latach 1943-1944. Wiele osób widziało na własne oczy masakry, w których ginęli członkowie ich rodzin, sąsiedzi, znajomi. W psychologii funkcja strachu jest zawsze jednakowa we wszystkich sytuacjach i polega na mobilizacji sił psychicznych i fizycznych na wszelkie przewidywane trudy i niebezpieczeństwa ${ }^{37}$. W wypadku Polaków mobilizacja obejmowała jednak wyraźnie uszczuplone siły, a dodatkowym problemem była motywacja do przełamania strachu. Próżno było jej szukać u części ocalonych, którym Ukraińcy zabili wszystkich krewnych i spalili cały dobytek. Nie zawsze moc strachu ustępowała dzięki alkoholowi ${ }^{38}$, posiadanej broni, pomocy partyzanckiej czy nawet chęci zemsty. Świadomość alienacji narodowej wśród żywiołu ukraińskiego potęgowała jego poczucie. Polacy często zasad-

ski obowiązek i dlatego do teraz jeszcze trwam na posterunku, ale nie wiem jak długo Pan Bóg mnie ochroni i doda mi sił do wytrwania”. Zob. więcej: J. Wołczański, op. cit., cz. I, s. 205, 337-338.

32 BOss., 16724/II, t. 1, k. 151, „Wacław Kopisto, Moje pokręcone losy, Wspomnienia. Od urodzenia do konspiracji na Wołyniu, lata 1911-1944".

33 W. E. Siemaszko, op. cit., s. 499.

${ }^{34}$ CAW, II/52.94, k. 6, Sprawozdanie sytuacyjne nr 4/44 emigracyjnego MSW RP za okres II-VI 1944 roku.

${ }^{35}$ Na wiadomość, że Polski Komitet Opiekuńczy w Rohatynie dla tysiąca Polaków organizuje wyjazd na zachód, kilka rodziny skupionych w samoobronie koło wsi Karolówka nie wytrzymało napięcia nerwowego i opuściło placówkę. Nastrój paniki miał opanować list komendanta Okręgu AK, w którym dowódca potwierdził słuszność decyzji o organizowaniu samoobrony. Zob. więcej: BOss., 16707/II, t. 2, k. 76, „Edward Polak: Los Polaka w latach 1939-1956”.

36 BOss., 16730/II, k. 166, Paweł Zaleski, „Wspomnienia wołyńskie”. Potwierdzają to raporty AK z Okręgu Lwowskiego z 1944 roku. Wskazywano w nich, że widoczne i odczuwalne zmęczenie Polaków w regionie wynika nie tyle z przeciągającej się wojny, ile przede wszystkim z mordów ukraińskich, które budziły duży lęk. Zob. więcej: BUW, mikrofilm 14382, k. 79, Raport dot. kwestii ukraińskiej z 7 VI 1944 roku.

37 J. Pieter, op. cit., s. 68.

38 J. Wołczański, Eksterminacja narodu polskiego i Kościoła rzymskokatolickiego przez nacjonalistów ukraińskich w Małopolsce Wschodniej w latach 1939-1945. Materiały źródłowe, cz. II, Kraków 2006, s. 563. 
nie uzewnętrzniali tę rozpacz potrzebą wskazania winnych ich stanu psychicznego. A winy upatrywali nie tylko wśród Ukraińców, domagając się po wojnie „radykalnego rozwiązania sprawy ukraińskiej”39. Zadawali również pytania: „gdzie nasz rząd, gdzie nasze władze, co na to mówi Warszawa, czemu nie przyjdą z jakąkolwiek pomocą?"40. Pojawiały się podejrzenia, że władze podziemne uważają eksterminację za mordy bandytów, z którymi Ukraińcy nie mają nic wspólnego ${ }^{41}$. To było nie tylko błagalne wołanie o pomoc zbrojną, ale także sygnał, że tracą wiarę w sens dalszego zamieszkiwania tych ziem. Te postawy w znacznym stopniu determinował właśnie strach. To m.in. jego siła sprawiała, że Polacy w jaśniejszych kolorach zaczęli wspominać niesławne przecież rządy radzieckie w latach 1939-1941. Niektórzy nawet wyczekiwali powrotu władzy bolszewickiej, która gwarantowałaby bezpieczeństwo przed banderowcami, a przynajmniej uniemożliwiłaby im mordowanie całej ludności ${ }^{42}$. To nie tylko było dowodem słabości polskiego podziemia w terenie. Te postawy, które konstytuował strach, w znacznym stopniu wpłynęły na pierwsze działania obronne społeczności polskiej. Były to ucieczki, ukrywanie się, migracje wewnętrzne i zewnętrzne, konwersje religijne, w różnych formach sygnalizowanie zagrożenia, akces do partyzantki akowskiej, bolszewickiej, a także policji wołyńskiej $\mathrm{z}$ hitlerowskiego nadania. W tym sensie strach stał się wypadkową zarówno reakcji Polaków na ich zabijanie, jak i przełomu w postawach ludzkich wobec tej polityki. Był to imperatyw w znacznym stopniu indywidualny i spontaniczny. Jego geneza nie wynikała $\mathrm{z}$ działań zinstytucjonalizowanych, ale pochodziła $\mathrm{z}$ pierwotnego instynktu samozachowawczego, jaki posiada każdy człowiek.

\section{Ukrainian massacres of the Polish people in Volhynia and Eastern Galicia in 1943-1944. Anthropology of fear}

The Poles in Volhynia and Eastern Galicia in 1943-1944 experienced extreme policy of the Ukrainian nationalists. It was supposed to lead to a total elimination of the Polish inhabitants from these territories (the policy of genocide). The specific atrocious and cruel methods of conducting extermination led by the Ukrainians were a main reason to generate the strong fear among the Poles. The memoirs of participants of these events and sources of Polish, Ukrainian and German organizations confirm that. The fear was deeper and more terrifying comparing to traumatic times of Soviet (1939-1941) and German (since 1941) invaders. It appeared in forms of panic, overwhelming mood, doubts and significant psychical exhaustion. However, it resulted not only from a Ukrainian activity, but also from the feeling of alienation of the Polish inhabitants on these lands, defencelessness and doubts of living in mother lands do not make sense. It is confirmed both by memoirs of participants of events and sources of Polish, Ukrainian and German organizations acting in those fields at that time. The consequences of widespread fear were very different and in extreme cases they led to mental illnesses. A very difficult task of "the

39 BOss., 16605/II, k. 201, „Sprawozdanie za czas do połowy grudnia 1943 r., opr. «Kisiel»«Wino-Iskra»".

${ }^{40}$ CAW, II/52.94, k. 6, Sprawozdanie sytuacyjne nr 4/44.

${ }^{41}$ BUW, mikrofilm 14381, k. 6, Raport nr 4 BIP-u Obszaru „Lwów” z 20 IV 1944 roku.

${ }^{42}$ Ibidem, k. 28, Raport „Janki” [W. Filipkowskiego]... 
Polish Underground State" was to overcome among the Poles a fear barrier, which enable to generate a motivation to an armed struggle and willingness to remain on those lands. The fear was overcome slowly and in different methods. It resulted mainly from an instinct of self-preservation which possesses each human. Eliminating the fear gave an impulse to initial defence activities of the Polish people at risk: escapes, hidings, access to Home Army and Bolshevik guerrillas as well as Volhynian policy subordinated to Nazis.

\section{Украинские убийства польского населении Волыни и Восточной Галиции в 1943-1944 г2. Антропология страха}

Поляки на Волыни и в Восточной Галиции в 1943-1944 гг. были подвержены экстерминационной политике украинских националистов, которая должна была привести к полному уничтожению польского населения этих территорий. Специфические способы проведения экстерминации, полные жестокости и решительности украинцев привели к тому, что среди польского населения этих территорий появился очень сильный страх. Он выступил в новом образе, несравнимом даже с ужасом политики оккупантов - советских в 1939-1941 гг., а также немецких. Этот страх принимал формы паники, настроений ужаса, сомнения, а также значительного психического истощения. Однако он был следствием не только украинских действий, но и чувства отчуждения польских автохтонов на этой территории, беззащитности а также сомнений в смысле дальнейшего проживания на земле предков. Это подтверждается так воспоминаниями участников событий, как и источниками из польских, украинских и немецких организаций, действовавших тогда на этой территории. Последствия распространенного страха были разными, в крайних случаях они доводили до психических расстройств. Очень трудной задачей польского вооруженного подполья было сломать среди поляков барьер страха, что создало бы у подверженного опасности населения мотивацию к вооруженной борьбе и желание остаться на этих землях. Победа над страхом происходила медленно и принимала разные формы. Это было следствие, в главной мере, инстинкта самосохранения, которым обладает каждый человек. Преодоление страха в себе порождало импульс к первым защитным действиям подверженного опасности польского населения: побегам, прятанию, вступлению в партизанские отряды (Армии Краеевой или большевистские), а также в подчиненную нацистам волынскую полицию. 